Brandeis $\mid$ urear

brandeis.edu/j-caste
CASTE: A Global Journal on Social Exclusion

Vol. 2 No. I pp. 67-76

April 2021

ISSN 2639-4928

DOI: $10.26812 /$ caste.v2i1.299

\title{
Manual Scavenging in India: The Banality of an Everyday Crime
}

\author{
Shiva Shankar' and Kanthi Swaroop ${ }^{2}$
}

\begin{abstract}
Manual scavenging is the practice of 'manually cleaning, carrying, disposing of, or otherwise handling, human excreta in an insanitary latrine or in an open drain or pit', and its existence is a crime of genocidal proportions. The vast majority of people forced into this degrading occupation are women from Dalit castes. The Government of India has outlawed the practice through two Acts of 1993 and 2013, yet it continues everywhere in the country. This essay argues that the persistence of this crime is a consequence of the criminal indifference of a casteist society, and that resistance to it has largely been the heroic effort of the victims alone.
\end{abstract}

\section{Keywords}

Manual Scavenging, Caste Atrocity, India, Dalit Women, Human Rights, Safai Karmachari Andolan

\section{The Unparalleled Social Abuse of Manual Scavenging}

'Manual scavenging' is the term used to describe the practice of 'manually cleaning, carrying, disposing of, or otherwise handling, human excreta in an insanitary latrine or in an open drain or pit,' and a 'manual scavenger' is a person engaged in or employed for manually carrying human excreta. These are definitions from The Employment of Manual Scavengers and Construction of Dry Latrines (Prohibition) Act, 1993 (Government of India, 1993). There are around

\footnotetext{
'Visiting Professor, Dept. of Electrical Engineering, Indian Institute of Technology Bombay, Mumbai ${ }^{2}$ Ph.D Candidate, Centre for Policy Studies, Indian Institute of Technology Bombay, Mumbai E-mail: shunyashankar@gmail.com
}

\section{Corresponding Author}

Kanthi Swaroop

E-mail: kanthiswaroop@iitb.ac.in

(C) 202I Shiva Shankar et al. This is an open access article distributed under the terms of the Creative Commons Attribution License, which permits unrestricted use, distribution, and reproduction in any medium, provided the original author(s) and source are credited. 
1.2 million people today who have been forced into this occupation. ${ }^{1}$ This number does not, however, include all the people who come into contact with raw excreta, for in India, excreta is not confined to private latrines, but also explodes into public spaces. Millions of people practice 'open defecation,' in rural as well as in urban areas, along river banks and railway tracks, in shrubland, forests, fields, and by the side of streets and roads in towns and cities (Gupta et al., 2020). Toilets in trains continue to discharge sewage directly onto the tracks (Paliath, 2019). Garbage dumps reek of faecal matter. Primitive and broken sewerage systems, where they exist at all, leak their contents regularly due to blockages caused by a citizenry that mindlessly flushes every kind of rubbish, including condoms and sanitary napkins, into it. Storm water drains carry sewage, not stormwater. Thus, an estimated five million safai karmacharis (sanitation workers) who clean and maintain public spaces also come into direct contact with human excreta (Bose, 2018; Das, 2018).

The Act of 2013, The Prohibition of Employment as Manual Scavengers and their Rehabilitation Act makes a few corrections: 'Manual scavenger' means a person engaged or employed, at the commencement of this Act or at any time thereafter, by an individual or a local authority or an agency or a contractor, for manually cleaning, carrying, disposing of, or otherwise handling in any manner, human excreta in an insanitary latrine or in an open drain or pit into which the human excreta from the insanitary latrines is disposed of, or railway track or in such other spaces or premises, as the Central Government or a State Government may notify, before the excreta fully decomposes in such manner as may be prescribed, and the expression 'manual scavenging' shall be construed accordingly (Government of India, 2013).

Nonetheless, large numbers of people who are sweepers, garbage collectors, waste pickers - millions of whom are children - and those who sort and recycle, all of whom need protection, still remain excluded from the ambit of these laws.

The central horror of manual scavenging is the fact that it is an inherited occupation, decided at the very birth, by caste. The overwhelming majority of people forced into scavenging are Dalits (people from castes once designated the 'untouchable'). Indeed, specific Dalit castes are designated as 'scavenging castes,' whose caste occupation is to clean. Their degraded status rests on toxic notions of purity and pollution that have haunted the Indic civilization for millennia. However, it is important to note that it was not people in 'impure' occupations who were subsequently labelled the 'untouchable' castes, but it was Buddhists who came to be declared 'untouchable' after the fall of Buddhism in India, and who were then forced into such occupations by an ascendent brahminical Hinduism; see for instance Ambedkar's seminal work Contempt for Buddhists as the root of untouchability (Ambedkar, 1990), or the work of Iyothee Thassar in Gail Omvedt (2003). Toynbee (1939) explains that 'caste is always on the verge of being a social enormity; but when caste is 'keyed up' by receiving a religious interpretation and a religious sanction in a society which is hag-ridden by religiosity, then the latent enormity of the institution is bound to rankle into a morbid social growth of poisonous tissue and monstrous proportions.' Manual scavenging is the most malevolent portion of this tissue. The horror is further compounded by the fact that over ninety percent of the victims are women. Caught at the intersection of

${ }^{1}$ This number is an estimate of the Safai Karmachari Andolan (Sanitation workers' movement), a pioneering movement fighting for the liberation of people engaged in the practice of manual scavenging. More details can be found here: www.safaikarmachariandolan.org 
caste and patriarchy, they bear the greatest burden of violence (Human Rights Watch, 2014; Singh, 2014).

Equipment that is provided for this work is brutally rudimentary. Women clean pit latrines with a piece of cardboard or metal to scrape and scoop, a broom to gather, and a basket in which to carry away the excreta. In provincial towns and villages, women set out early morning, moving from house to house, from latrine to latrine, and when the basket is full, trudge to some dumping ground to empty it. The basket itself, heavy with its load, must be carried on the head; this is the most 'despicable and inhumane practice of head loading' (Jan Sahas, 2014). It leaks, and when it rains, it pours. Day after day, without a break, without a day off, this horror plays itself out into the exhausted lives of the women (Human Rights Watch, 2014).

Men are forced into one of the most dangerous forms of sanitation labour in the world. They must descend into septic tanks, at the end of a rope, and empty out its contents with a bucket. They must dive into sewage drains, holding their breath, and clear blockages with bare hands. As for rummaging in the countless faeces-laced mounds of rubbish that infest the towns and cities of India for something to sell, an army of hungry men, women and children roam the streets every day. ${ }^{2}$

This is genocidal level of violence that is visited upon the most discriminated and vulnerable citizens of the country, as we argue next.

\section{The Charge of Genocide}

Manual scavenging is forced labour. Women are paid 25 or 30 rupees (about 35 U.S cents), a month, by a household for cleaning their pit latrines. ${ }^{3}$ Sometimes, wages are pieces of leftover bread, a little grain once a year, and discarded clothes (Kumar \& Preet, 2020; Singh, 2014). Men earn around Rs. 500 for manually cleaning a septic tank in an apartment complex. Municipalities in towns and cities hire labour on a contract basis to clean. The road to permanent employment is hard and long, and most sanitary workers remain stuck as daily wage labourers. With increasing privatisation of sanitary work, wages have plummeted; for example, in metropolitan Hyderabad, an IT and software hub, a sanitary worker is paid Rs. 8000 a month. ${ }^{4}$ What does such a wage connote, in practical terms? A household with national average of 4.4 members which is dependent for its sustenance on this wage is condemned to poverty, as defined by the (conservative) urban poverty line recommended by an expert group of the Indian Planning Commission in 2014 (Government of India, 2014). Often these paltry wages are paid months later; recently workers in Delhi, the capital of the country, went on strike protesting they had not been paid for five months (Misra, 2021). Privatisation can also mean sudden loss of employment; recently the Chennai Municipality sacked over two thousand employees, even though they had worked for decades on contract in the hope of a permanent position (The Hindu, 2021).

Sanitation workers suffer from trauma, and debilitating diseases such as asthma, rotavirus, hepatitis, and terrible skin disorders caused by daily contact with excreta,

${ }^{2}$ There are an estimated 200,000 waste pickers in Delhi alone: Global Alliance of Waste Pickers, https://globalrec.org/city/new-delhi/

${ }^{3}$ Wages were Rs. 10 to 20 per household in 2014, see for instance (Jan Sahas, 2014); they have gone up marginally, and one supposes, grudgingly.

${ }^{4}$ This figure is based on interviews conducted with Sanitary workers between October and December 2018. 
yet they are not provided elementary health insurance. Their life expectancy is less than $50^{5}$ years in a country where it is over 69 for the rest of the population. ${ }^{6}$ Men who clean septic tanks and sewage drains die on average by 32 (Swaroop, 2019). The cause of death is predominantly occupational: asphyxiation in a septic tank, drowning in sewage, tuberculosis, cholera, meningitis, and various cancers. Yet there is no life insurance for the sanitation worker, and the elementary compensation guaranteed by the Acts of 1993 and 2013 is rarely ever provided to the worker's family.

The immediate question that would occur to a person not familiar with the social realities of India, would be on the nature of the force that holds up such a system of oppression. The short answer is that, as always, it is violence. Here it is the violence of the 'unparalleled social abuse of untouchability' (Toynbee, 1939).

First is the constant background threat of physical violence. Violence against all Dalits is a reality, and the Swachakar Community, belonging to the so-called 'scavenging castes' or Dalits amongst the Dalits, who are at the bottom of the caste heap, bear the brunt of the entire system. They are routinely abused, and women are threatened with physical violence and social boycott if they do not show up for work. There is also the larger threat of abuse of the entire family. Periodic eruptions of violence go largely unnoticed; a few reach the level of news.

Then there is the violence of social exclusion (The Hindu, 2021). In villages and mofussil towns, habitations of sanitation workers are located at the edge, downwind, next to the garbage dumps (Lee, 2017). The ordinary everyday activities of fetching water or buying food become hurdles to cross, inviting beatings for infractions such as touching a tap or entering a shop. Those who try and fight their way out of this hell by seeking other employment suffer social boycott, and are forced back into manual scavenging (Amrita, 2021). In cities, they are crowded into slums and low-grade tenements. Sometimes, several families must share a one room apartment. Often, when a sanitation worker dies before retirement, the only way the family can escape eviction, and a homeless life on the streets, is for the spouse, or son, to inherit the job (Olwe, 2013; Salve et al., 2017). The study by Sripad and Ashish (2012) finds 'considerable intergenerational occupational persistence - across all occupational categories, the father's category is the most likely one that a son could find himself in ... But, there are differences across occupational categories - the probability that a son would fall in the father's category is higher for the low skilled/low-paying occupations.' In some parts of the country sanitary workers can formally bequeath their jobs to their kin as a right of inheritance (Salve et al., 2017). These are some of the many ways sanitation work is rendered hereditary and reified as flesh by the caste system.

This violence is all pervasive. Anganwadi centres, run by the state governments to provide elementary help to combat malnutrition and hunger in infants, discriminate against children of sanitary workers, if they admit them at all. In schools, they are relegated to the back of the class, and face casteist abuse from their teachers and classmates. Children are sometimes forced to clean toilets and clear the school ground of animal carcasses; such abuse has been inflicted even on doctoral students (Jafri,

${ }^{5}$ This is based on the findings of the study 'Status of Scavenging Communities in India' carried out by 12 Community Based Organizations (CBOs) in five states: Andhra Pradesh, Gujarat, Karnataka, Tamil Nadu, and Gujarat. More facts on the current status of scavenging communities can be found here: https://counterview.org/2014/01/15/a-new-study-finds-thatmanual-scavengers-in-india-live-in-segregated-localities-without-any-social-or-economicprotection/

${ }^{6}$ World Bank Data, https://data.worldbank.org/indicator/SP.DYN.LE00.IN?locations=IN 
2019). Discrimination persists after death. In villages and towns, there are separate burial and cremation grounds for different castes, the distant degraded spaces reserved for the Swachakar Community.

The most insidious violence is the psychological trauma that envelops a person treated thus from infancy; it seeps within and blights the soul. Sanitary workers drink alcohol to steel themselves to enter a sewage drain, or just to forget the horror. They chew tobacco to mask the stench of excreta, and oral cancer is a consequence. The tumour that hollows out a face is the visible body-sign on the sanitation worker produced by the stigma of caste. Even those who have fought against all odds and are doctors or lawyers, bear the invisible scars of violence where even the caste name is a taunt and an abuse. For as Ambedkar wrote, 'in India a man is not a scavenger because of his work. He is a scavenger because of his birth irrespective of the question whether he does scavenging or not' (Ambedkar, 1991).

Such heightened violence amounts to mental and physical torture, and is in violation of every provision of the United Nations Convention against Torture and Other Cruel, Inhuman or Degrading Treatment or Punishment (1987). We argue that the existence of manual scavenging is in fact a crime of genocidal proportions, akin to slavery (Patterson, 1951), which especially targets Dalit women. Indeed, Article II of the Genocide Convention states: In the present Convention, genocide means any of the following acts committed with intent to destroy, in whole or in part, a national, ethnical, racial or religious group, as such: (a) Killing members of the group; (b) Causing serious bodily or mental harm to members of the group; (c) Deliberately inflicting on the group conditions of life calculated to bring about its physical destruction in whole or in part; (d) Imposing measures intended to prevent births within the group; (e) Forcibly transferring children of the group to another group (1948 Convention on the Prevention and Punishment of the Crime of Genocide, 1951).

We have established clauses (b) and (c) beyond doubt; that sanitary workers die twenty years earlier than the average citizen is proof of wilful murder, as Bezwada Wilson has pointed out repeatedly. ${ }^{7}$ We now seek to establish the most crucial aspect in a charge of genocide, namely intent.

It might seem that contrary to our charge, the intentions of the governments that passed the two Acts in 1993 and 2013 must certainly have been to abolish this abominable crime. But how then is one to understand the fact that it is the government that employs the largest number of manual scavengers, to clean railway stations and tracks, schools and hospitals, courts and jails? Tens of thousands of people are pressed into cleaning railway tracks of excrement alone (see also the chapter 'Indian Railways and Manual Scavenging' in (Singh, 2014)). How is one to digest the fact that not one person has ever been convicted for employing manual scavengers in the nearly three decades of the 'implementation' of these laws (The Wire, 2019)?

It has been argued elsewhere, for instance in (Akhilesh, 2020; Shankar \& Swaroop, 2020), that these Acts are not really concerned with the liberation of people involved in manual scavenging, and that they are only exercises in obfuscation. It suffices here for us to observe that the government refuses to even list all the victims. It refuses to honour its commitment to rehabilitate manual scavengers and provide them alternative employment on the flimsiest of pretexts. Under a misconceived Swach Bharat Abhiyan,

\footnotetext{
${ }^{7 ‘}$ Stop Killing Us,' Hundreds Gather At Jantar Mantar To Protest Deaths Of Sanitation Workers, The Logical Indian, 26 Sep 2018.https://thelogicalindian.com/news/sanitation-workers-protestdelhi/
} 
the government has constructed millions of toilets connected to single pits or septic tanks. Emptying those especially in rural India, will require human handling of faecal matter. The incidence of manual scavenging is only going to see an enormous increase.

Governments and municipalities intentionally recruit people from specific Dalit castes into scavenging occupations; this intention is not just a consequence of the caste system, it is the caste system, in thought and in action. The crime of manual scavenging thus rests on the caste system, is enforced by the caste system, and is fed and nourished by the caste system. Caste is the embodiment of intent, specifically the intention that some people, determined at birth, must scavenge for a living. Caste is the social structure by means of which this intent is translated into practice. As caste is intertwined with patriarchy, most of the victims are women. That such a living is precarious and life threatening is of no concern to the rest of the society. One person's suffering does not evoke compassion in another person, of another caste. Caste has rendered suffering banal.

\section{Against the Crime of Indifference}

Perhaps the most incomprehensible aspect of manual scavenging is that it occurs in broad daylight, under the public gaze of people hurrying to their offices, markets, and schools, or people simply standing, watching. A train disgorges its hundreds of passengers, none of whom seems able to notice the women cleaning excreta from the tracks. Possibly they notice, but do not register the horror. Or perhaps they register, and do not care.

It is this indifference of the citizenry that permits repeated and flagrant violations of the Acts of 1993 and 2013 which their own representatives have enacted into legislation. It is the citizenry who can either breathe life into legislation, or let it wither. In a country that records the death of a sanitation worker by asphyxiation in a septic tank or sewer every two days, its citizens have chosen to apathetically look away. It is an unthinking, unfeeling, baleful indifference, a lack of elementary imagination, a banality in Arendt's telling (1963).

Ambedkar observed that this indifference is no accident, and that it is the inevitable product of a society fractured into some six thousand castes and subcastes, arranged in hierarchical order of 'ascending sense of reverence and descending sense of contempt.' In his analogy, 'Hindu society is a tower which has several storeys without a ladder or an entrance. One is to die in the storey in which one is born.' Isolated in their different psychological worlds there is no possibility of collective action against injustice, for 'caste is not just a division of labour, it is a division of labourers' (1979). Indeed, there is not even a common notion of justice that transcends caste; there are no universal moral or ethical principles that bind all the people together in a common social compact which is respectful of all. Instead there is social consensus, especially amongst the dominant castes, which supports and enforces inequality, untouchability, manual scavenging.

Thus, resistance has largely been the effort of the Swachakar Community alone. Everywhere across the country, sanitation workers are delving into their own resources and fighting for their human and civil rights. Organizations such as Janodayam, READ, Navsarjan Trust, Social Development Foundation, Thamate, Jan Sahas Social Development Society, and the most remarkable Safai Karmachari Andolan, are at the forefront of the war against manual scavenging (Ramaswami, 2005). From legal 
action to supporting the education of children, these organizations are nurturing the flames of a revolution. Their work is on par with the greatest liberation movements in the history of the world. It commands our deepest respect and deserves all recognition including the Nobel Prize for Peace. Thousands of women have burnt their 'brooms and baskets of indignity,' and sworn that they would rather starve than scavenge for a living; hundreds of thousands have educated their children and facilitated their escape to a better life in the city!

Bertrand Russell warned us that it is our crime of silence that is responsible for the genocidal wars of imperial aggression, especially the silence of the citizens of the Empire (Duffett, 1968). Here it is the shameful indifference of the citizens of India that is responsible for the crime. The citizens must realise this truth, assume responsibility, and join forces with the Swachakar Community in their struggle for justice. The Government of India on its part must seek every avenue to fight caste discrimination. Intergovernmental agendas, such as Sustainable Development Goals, must 'emphasize caste as a fundamental determinant of social-exclusion, inequality, poverty, and discrimination' (Mosse, 2018). The first step towards solving a problem is to acknowledge that it exists. The United Nations Human Rights Council and other human rights organizations must include manual scavenging in their list of crimes against humanity and campaign against it, for as we have argued, its prohibition is a jus cogens norm. It is when good people all over the world join the war against this unparalleled social abuse of manual scavenging that it will be finally won.

\section{Acknowledgements}

We dedicate this article to Bezwada Wilson and Safai Karmachari Andolan. We are very grateful to Hemangi Kadlak, Priyanka Preet, S. Subramanian, and N. Usha Rani for many important suggestions. We would also like to record here the power of Sudharak Olwe's photo essays (Olwe, 2013, 2019), which we strongly recommend as introductory reading for those who would like to be better informed about the crime of manual scavenging.

\section{References}

Akhilesh, P. (2020, September 21). Failing the sanitation worker again. The Indian Express, p. 6. Ambedkar, B. R. (1979). Annihilation of caste. In V. Moon (Ed.), Dr. Babasaheb Ambedkar: writings and speeches, vol. 1. Mumbai: Government of Maharashtra Press.

- (1990). The untouchables, who were they and why they became untouchables? In V. Moon (Ed.), Dr. Babasaheb Ambedkar: writings and speeches, vol. 7. Mumbai: Government of Maharashtra Press.

- (1991). What Congress and Gandhi have done to the untouchables. In V. Moon (Ed.), Dr. Babasaheb Ambedkar: writings and speeches, vol. 9. Mumbai: Government of Maharashtra Press.

Amrita. (2021, January 11). In India, manual scavenging goes beyond an occupation: it's a human rights issue, youthkiawaaz.com. Retrieved on February 08, 2021 from https://www. youthkiawaaz.com/2021/01/ explained-manual-scavenging-where-are-we-and-the-systemgoing-wrong/

Arendt, H. (1963). Eichmann in Jerusalem: a report on the banality of evil. New York: The Viking Press. 
Bajaj, S., and Venugopalan, A. (2018, October 4). Rs 10 Lakh: The price of a manual scavengers' life, for those who survive, rehabilitation and compensation are hard to come by. The Wire, Retrieved on January 23, 2021 from https://thewire.in/rights/manual-scavengers-tamilnadu-rehabilitation-compensation

Bose, R. (2019, December 18). For women safai karamcharis, 'liberation' is manual scavenging with a makeover. News18.com, Retrieved on January 23, 2021 from

https://www.news 18.com/news/buzz/for-women-safai-karamcharis-liberation-is-manualscavenging-with-a-makeover-2400809.html

Das, S. (2018, October 1). Govt must get its hands dirty to rescue manual scavengers. Down To Earth, Retrieved on February 02, 2021 from https://www.downtoearth.org.in/news/ waste/ govt-must-get-its-hands-dirty-to-rescue-manual-scavengers-61756

Duffett, J. (Ed.) (1968). Against the crime of silence. Proceedings of the International War Crimes Tribunal. Stockholm - Copenhagen. New York: Clarion.

Government of India. (1993). The Employment of Manual Scavengers and Construction of Dry Latrines (Prohibition) Act, 1993. Government of India. Retrieved on January 18, 2021 from https://legislative.gov.in/sites/default/files/A1993-46_0.pdf

- (2013). The Prohibition of Employment as Manual Scavengers and their Rehabilitation Act, 2013. Ministry of Law and Justice. Retrieved on January 18, 2021 from http://www. egazzette.nic.in/WriteReadData/2013/E_35_2013_385.pdf

- (2014). Report of the expert group to review the methodology for measurement of poverty. Planning Commission of India. Retrieved on February 23, 2021 from http://14.139.60.153/ bitstream/123456789/410/1/Report-REPORT OF THE EXPERT GROUP TO RECOMMEND THE DETAILED METHODOLOGY FOR IDENTIFICATION OF FAMILIES LIVING BELOW POVERTY LINEIN THE URBAN AREAS.pdf

Gupta, A., Khalid, N., Deshpande, D., Hathi, P., Kapur, A., Srivastav, N., Vyas, S., Spears, D., and Coffey,D.(2020). Revisiting open defecation: evidence from a panel survey in rural north India, 2014-18. Economic and Political Weekly, 55(21), 55-63 . Retreived on April 04, 2021 from https://www.epw.in/ 2020/21/special-articles/revisiting-open-defecation.html\%

Human Rights Watch. (2014). Cleaning human waste: manual scavenging, caste, and discrimination in India. Retrieved on January 23, 2021 from https://www.hrw.org/ report/2014/08/25/cleaning-human-waste/manual-scavenging-caste-and-discriminationindia

Jafri, A. A. (2019, May 31). Two Dalit research scholars 'forced to clean toilet' by professor at Banaras Hindu University. NewsClick.in, Retrieved on February 01, 2021 from https:// www.newsclick.in/2-dalit-research-scholars-forced-clean-toilet-professor-BHU

Jan Sahas. (2014). Socio economic status of women manual scavengers. UN Women, Fund for Gender Equality. New Delhi.

Kumar, S., and Preet, P. (2020). Manual scavenging: women face double discrimination as caste and gender inequalities converge. Economic and Political Weekly (Engage), 55(2627). Retrieved on February 10, 2021 from https://www.epw.in/engage/article/manualscavenging-women-face-double-discrimination-caste-gender

Lee, J. (2017). Odor and order: how caste is inscribed in space and sensoria. Comparative Studies of South Asia, Africa and the Middle East, 37(3), 470-490. Retrieved from https:// doi.org/10.1215/1089201x-4279188

Misra, S. (2021, January 14). Not paid for months, 22,000 Delhi civic workers threaten to boycott vaccine drive duties. The Print, Retrieved on February 15, 2021 from https://theprint.in/ india/not-paid-for-months-22000-delhi-civic-workers-threaten-to-boycott-vaccine-driveduties/585014/ 
Mosse, D. (2018). Caste and development: Contemporary perspectives on a structure of discrimination and advantage. World Development, 110, 422-436. Retrieved from https:// doi.org/10.1016/j.worlddev.2018.06.003

Olwe, S. (2013). In search of dignity and justice: the untold story of Mumbai's conservancy workers. Retrieved on February 15, 2021 from www.galli.in

- (2019). Including the excluded. Retrieved on February 15, 2021 from https://www. sudharakolwe.com/sanitation-workers.html

Omvedt, G. (2003). Buddhism in India: challenging Brahmanism and caste. New Delhi: Sage Publications.

Paliath, S. (2019, October 13). Without Mechanisation \& Modern Sewage Systems, Swachh Bharat an Illusion: Bezwada Wilson. IndiaSpend, Retrieved on February 06, 2021 from https://www.indiaspend.com/without-mechanisation-modern-sewage-systems-swachhbharat-an-illusion/

Patterson, W. (Ed.) (1951). We charge genocide: the historic petition to the United Nations for relief from a crime of the United States Government against the Negro People ( $1^{\text {st }}$ edition). Civil Rights Congress.

Ramaswami, G. (2005). India stinking: manual scavengers in Andhra Pradesh and their work. Navayana.

Saha, S., and Upadhayay, V. (2021, January 18). The missing manual scavengers of India. Down To Earth. Retrieved on February 03, 2021 from https://www.downtoearth.org.in/blog/water/ the-missing-manual-scavengers-of-india-75104

Salve, P., Bansod, D., and Kadlak, H. (2017). Safai karamcharis in a vicious cycle: a study in the perspective of caste. Economic and Political Weekly, 52(13). Retrieved on January 24, 2021 from https://www.epw.in/journal/2017/13/perspectives/safai-karamcharis-aviciouscycle.html

Shankar, S., and Swaroop, K. (2020). When it comes to manual scavenging, enacted laws have persistently failed. The Wire, Retrieved on February 15, 2021 from https://thewire.in/rights/ persistent-failure-enacted-laws-end-

Singh, B. (2014). Unseen: the truth about India's manual scavengers. New Delhi: Penguin Books India.

Sripad, M., and Ashish, S. (2012). How close does the apple fall to the tree? some evidence on intergenerational occupational mobility from India. Economic and Political Weekly, 47(40), 56-65. Retrieved on March 02, 2021 from https://www.epw.in/journal/2012/40/specialarticles/how-close-does-apple-fall-tree.html

Swaroop, K. (2019, June 11). India's manual scavengers: ugly truths of unsanitary sanitation work an open secret, law needs better enforcement. First Post, Retrieved on March 02, 2021 from https://www.firstpost.com/india/indias-manual-scavengers-ugly-truths-of-unsanitarysanitation-work-an-open-secret-countrywide-law-needs-better-enforcement-6791721.html

The Hindu. (2021, February 14). Conservancy workers petition PM on losing jobs to privatisation. The Hindu, Retrieved on February 22, 2021 from https://www.thehindu.com/ news/cities/chennai/conservancy-workers-petition-pm/article33832946.ece

The Wire. (2019, July 10). No reports of people being convicted for employing manual scavengers: centre. The Wire, Retrieved on February 05, 2021 from https://thewire.in/rights/ manual-scavenging-ramdas-athawale-parliament-questions

Toynbee, A. (1939). The breakdowns of civilizations. In A. Toynbee (Ed.), A study of history (Vol. 4, pp. 229-232). London: Oxford University Press. 
UN. (1948). Convention on the prevention and punishment of the crime of genocide, Pub. L. No. 260 A (III) of 9 December 1948 (1951). Retrieved on February 22, 2021 from https:// www.un.org/en/genocideprevention/documents/atrocity-crimes/Doc.1_Convention on the Prevention and Punishment of the Crime of Genocide.pdf

- (1987). Convention against torture and other cruel, inhuman or degrading treatment or punishment, Pub. L. No. 39/46 of 10 December 1984 (1987). Retrieved on February 25, 2021 from https://www.ohchr.org/en/professionalinterest/pages/cat.aspx 